\title{
Introduction: Safeguards and Limits of Judicial Power
}

Citation for published version (APA):

Hirsch Ballin, E., Van der Schyff, G., \& Stremler, M. (2020). Introduction: Safeguards and Limits of Judicial Power. In E. Hirsch Ballin, G. Van der Schyff, \& M. Stremler (Eds.), European Yearbook of Constitutional Law 2019: Judicial Power: Safeguards and Limits in a Democratic Society (pp. 3-12). TMC Asser Press. European Yearbook of Constitutional Law Vol. 1 https://doi.org/10.1007/978-94-6265-359-7_1

Document status and date:

Published: 01/01/2020

DOI:

10.1007/978-94-6265-359-7_1

Document Version:

Accepted author manuscript (Peer reviewed / editorial board version)

\section{Please check the document version of this publication:}

- A submitted manuscript is the version of the article upon submission and before peer-review. There can be important differences between the submitted version and the official published version of record.

People interested in the research are advised to contact the author for the final version of the publication, or visit the DOI to the publisher's website.

- The final author version and the galley proof are versions of the publication after peer review.

- The final published version features the final layout of the paper including the volume, issue and page numbers.

Link to publication

\footnotetext{
General rights Owners
rights.

- You may freely distribute the URL identifying the publication in the public portal. please follow below link for the End User Agreement:

www.umlib.nl/taverne-license

Take down policy

If you believe that this document breaches copyright please contact us at:

repository@maastrichtuniversity.nl

providing details and we will investigate your claim.
}

Copyright and moral rights for the publications made accessible in the public portal are retained by the authors and/or other copyright owners and it is a condition of accessing publications that users recognise and abide by the legal requirements associated with these

- Users may download and print one copy of any publication from the public portal for the purpose of private study or research.

- You may not further distribute the material or use it for any profit-making activity or commercial gain

If the publication is distributed under the terms of Article $25 \mathrm{fa}$ of the Dutch Copyright Act, indicated by the "Taverne" license above, 


\title{
Chapter 1 \\ Introduction: Safeguards and Limits of Judicial Power
}

\author{
Ernst Hirsch Ballin, Gerhard van der Schyff and Maarten Stremler
}

\subsection{Judicial Power and Judicial Independence}

This first volume of the European Yearbook of Constitutional Law is devoted to the theme of judicial power. Countless treatises on the judiciary have preceded the publication of this yearbook. Although the various authors of this volume have naturally relied on these preceding publications, they have also chosen on this occasion to focus on a specific angle, in which the power of judges has been problematised. By taking binding decisions, judges exercise farreaching powers. While their decisions can protect, they can also seriously limit the freedom of citizens or otherwise determine how this freedom is used. Modern courts can also influence and even drive processes of national transformation such as in post-conflict societies, or processes of integration and constitutionalization such as that of the European project. ${ }^{1}$ Judicial power needs, as a consequence of such potential, to be subject to constraints. The common phrase of 'judicial independence' suggests the absence of restraint. In the context of a constitutional democracy, however, no power can be absolute and without some element of restraint or confinement. Hence the demand for safeguards and limits on judicial power. The authors of this yearbook analyse and discuss these safeguards in a variety of constitutional systems, both at a national and supranational level in Europe and beyond.

According to the classical doctrine of 'judicial independence', independence indicates the absence of opportunities for politics and governance to influence the judiciary. ${ }^{2}$ The judicial independence recognised in human rights treaties and many constitutions - whether credible or otherwise - is designed to ensure that the judiciary is impartial and not subject to instructions from other state powers. While the separation of state powers is intended to serve as a blueprint for this, judicial independence does not exist in a separate or parallel universe. Instead, the judiciary is part of the constitutional system and operates within a legal order that connects the citizens and powers of that state to each other. Looking at judicial independence from this broader perspective, the traditional trias politica would appear no longer to adequately represent the diversity and complexity of constitutional systems and their democratic legitimacy in today's world. ${ }^{3}$

Tim Koopmans, for example, has characterised modern constitutionalism as 'bipolar' . By this he means that political institutions, understood as the executive and the legislature, are nowadays held to account not only through elections and political checks and balances, but also through review by national and supranational courts. This development, which amounts to a reconfiguration of the trias politica, highlights the need for a new assessment of judicial power in the contemporary constitutional context. Similarly, the political theorist Pierre Rosanvallon speaks of the 'judicialisation of politics', by which he means the tendency of citizens to use the

\footnotetext{
${ }^{1}$ For analyses of the transformative function with a focus on the Constitutional Court of South Africa, see Robertson 2010, pp 255-270 and Chap. 8 by Venter in this volume. See Stone Sweet 2004, pp 64-96 for an account of the constitutional impact of the European Court of Justice (and its dialogue with national courts), and compare Claes 2006, who develops a 'bottom-up' view in this regard centred on the perspective of national courts in the European Union.

${ }^{2}$ Consider Bell 2006, pp 26-29. See also Venter 2010, pp 67-70.

${ }^{3}$ Ackerman 2017, p 40.

${ }^{4}$ Koopmans 2013, pp 248-251.
} 
judicial process in order to achieve what they fail to accomplish via the ballot box. ${ }^{5}$ This he views as an example of 'counter-democracy', understood to mean an expression of democratic distrust that actually serves to buttress and complement electoral democracy instead of fundamentally opposing it.

Also illustrating the limits of the trias politica as a definitive frame of analysis, Mark Tushnet points not only to the emergence of the administrative state as a fourth branch of governance, but also to a possible fifth branch. ${ }^{6}$ The latter branch would address the need in modern systems of governance to prevent constitutional corruption and decay and address conflict-of-interests problems that do not easily fit the separation of powers. This branch he distinguishes from the judiciary, while noting that institutions within the new branch might take some inspiration from the courts in wanting to combine independence and accountability - but probably in a different configuration to that found in courts. ${ }^{7}$ Tushnet also explores what he describes as going beyond the fifth branch. This pertains to a discussion of Roberto Mangabeira Unger's proposal to create a 'destabilization branch' with which to interrupt routines and prevent ossification in social institutions, to which government bureaucracies and agents also belong. ${ }^{8}$ This is definitely appealing as a way to conceptualise judicial power today, given that courts can and do destabilise bureaucracies in the service of constitutional rights in this manner. ${ }^{9}$ There is also no denying that acting in this way courts generate political controversy, which leads to questions about the proper role of the judicial function. ${ }^{10}$

Observations and discussions like these reinforce, once more, the need to look afresh at judicial power in its present-day context.

Many treatises on judicial independence focus on the need to ensure an absence of risks emanating from politics and governance. There are good reasons for this. But while the importance of insulating the judiciary from improper political pressure exerted by members of the executive or legislature can hardly be over-emphasised, this yearbook investigates the idea of judicial independence somewhat differently: not in an - untenable - conceptual separation, such as the traditional notion of separation of powers would seem to involve, but instead as an institutionalizing of relationships that legitimise the power of the courts. No institution in a constitutional democracy can have its legitimacy in isolation; legitimacy is acquired within the wider context of the constitutional system as a whole. The judiciary is part of the state system and operates in a legal order that connects the citizens and institutions of that state - increasingly in a multi-level environment. The notions of 'safeguards' and 'limits' indicate the reciprocally enabling and protecting nature of these relationships.

In recognition of this, the contributions to this volume analyse these safeguards and limits as relations existing within a complex constitutional architecture. The authors, coming from a variety of legal cultures, mainly European, demonstrate the diversity of these relations. Despite the simplicity of the trias politica model, a constitutional order is characterised by complexity. However, this must not lead to instability with regard to fundamental characteristics, such as judicial independence. This architecture is not a fixed system; it can only work and retain its legitimacy if it is able to absorb internal and external system turbulences appropriately, while also continuing to uphold its constitutional principles.

\footnotetext{
${ }^{5}$ Rosanvallon 2008, pp 8; 227-247.

${ }^{6}$ Tushnet 2018, pp 107-123.

${ }^{7}$ Ibid, p 119.

${ }^{8}$ Ibid, pp 123-124.

${ }^{9}$ Ibid, p 125.

${ }^{10}$ Ibid.
} 


\subsection{Judges in a Democratic Society}

A constitutional democracy is the organizational framework for opinion-forming and decisionmaking for a democratic society. The phrase 'democratic society' plays a central role in the European Convention on Human Rights and Fundamental Freedoms. ${ }^{11}$ It functions like a chorus, as the only situation in which legislators may impose restrictions on fundamental rights such as the freedom of expression and the freedom of religion is when these restrictions are 'necessary in a democratic society'. When it comes, however, to the fundamental rights of fair trial and an effective remedy (Articles 6 and 13), such restrictions seem out of place because access to justice serves and guarantees the democratic society in which fundamental rights are to be effected.

Here, however, we encounter an antinomy ${ }^{12}$ that is currently contributing to serious tensions around judicial independence, and specifically the question of how to prevent a situation in which judges exercising their independence become detached from the democratic society that they are required to protect. In a number of European countries, populist parties, which all came to power on the basis of free elections, have recently attempted to thwart the independence of the judiciary. ${ }^{13}$

In many countries, the judiciary is the frontline where questions of legitimacy and populist criticism of supposed elitism manifest themselves. This is made particularly clear in the contribution to this volume by Dimitry Kochenov and Petra Bárd. Discussing developments in Hungary and Poland in Chap. 11, they describe how autocratic regimes, operating in the name of 'democracy' and under the pretext of 'reform', have curbed the powers of the courts and effectively captured the judiciary. They also note that while the political institutions of the European Union seem to lack the political will to take concrete measures in the face of what the authors call 'rule of law backsliding' in the Member States, the Court of Justice is developing new case law contributing to the formation of supranational standards of judicial independence.

The discussions about how the European Court of Human Rights (ECtHR) perceives its responsibilities are another manifestation of the aforementioned tension. This becomes clear from the debate in this volume between Marc Bossuyt, the former President of the Constitutional Court of Belgium, and Egbert Myjer, former judge on the bench in Strasbourg. While Bossuyt in Chap. 13 contends that the Strasbourg Court has been expanding its mandate by attributing positive obligations to civil rights and by its close scrutiny of asylum cases in the absence of an express right to asylum in the Convention, Myjer in Chap. 14 counters that the High Contracting Parties have never criticised the Court for interpreting the Convention 'without borders'. Myjer recalls that the Court interprets the Convention as a living instrument in the light of present-day conditions and mentions the duty of the Court to protect the rights and freedoms of those residing within its jurisdiction.

\subsection{Varieties of Safeguards and Limits}

Constitutional jurisdiction, whether as a separate discipline or otherwise, occupies a distinguished place in this yearbook. The contributions relate mainly to continental European, codification-based legal systems, with contributions from countries representative of various parts of the continent. But Brexit or not, the question of how to prevent a situation in which

\footnotetext{
${ }^{11}$ Van der Schyff 2005, pp 198-211.

12 The notion of antinomies between fundamental constitutional decisions was coined by Norbert Achterberg. See Achterberg 1969.

${ }^{13}$ See the contributions by Gábor Attila Tóth, Dimitry Kochenov and Kim Lane Scheppele in Adams et al 2017. See also AIV 2017.
} 
judges exercising their independence become detached from the democratic society that they are required to protect also arises in the world of common law. That is why this yearbook also gives a place to judicial independence in the legal system of England and Wales, as well as to the legal system of South Africa, where civil and common law traditions meet in a constitutional framework that a quarter of a century ago, after the abolition of Apartheid, was just starting out on the path towards building a democratic society.

While all the countries discussed in this yearbook can be regarded as constitutional democracies, the individual chapters demonstrate that the safeguards and limits to judicial power vary considerably. As Geerten Boogaard explains in Chap. 5 on the Netherlands, this diversity is the result of historical developments, which are different for each state. The principle that judges are independent of the legislature and executive can safely be said to be a common point of departure in most constitutional systems. But while in some countries the financial and organizational position of the judiciary is also included in the constitutional setup, this dimension is lacking in others.

The method of appointing judges is a characteristic of their independence, or lack of it. In the Netherlands, appointments of judges are traditionally for life and made by Royal Decree on the proposal of the Minister of Justice. In the case of appointments to the Supreme Court (i.e. the Court of Cassation), the House of Representatives (the Chamber of Deputies) nominates three people, while other judges are appointed on a recommendation from the Council for the Judiciary. The role of the Minister of Justice has gradually been reduced to a procedural one, without any amendments to the Constitution in this respect. From this we can see that independence depends not only on explicit constitutional standards, but also on conventions and other behavioural patterns that have developed over time in the relationship between the highest state institutions.

Like Boogaard does for the Dutch judiciary, Alfonso Celotto in Chap. 4 situates the position of the Italian Constitutional Court in a bipolar schema of constitutional relationships. Judges in Italy rule on constitutional questions, but not as the sole actors. Although the Italian Constitution firmly and clearly enshrines the Constitutional Court in its legal system, Celotto observes a greater measure of restraint in the Court's relationship with the country's political institutions than in its relationship with other courts.

Paul Daly in Chap. 7 outlines the highly contrasting position of the British judiciary, with a particular focus on the legal system of England and Wales. The whole constitutional development of the United Kingdom is one of principled pragmatism rather than system design. For instance, the Supreme Court in that country has no normative basis to place its judgement on the constitutionality of laws above that of Parliament. Judicial pay and pensions are vulnerable to changes in the political climate. What is even more remarkable is the way in which the other highest state organs relate to the judiciary. Based on recent examples, these arrangements would appear to be insufficiently characterised by an awareness of the constitutional value of courts' independent jurisdiction.

In contrast to the principled pragmatism of British constitutionalism, the South African system can rightly be regarded as an example of constitutional design, and even grand design. Francois Venter explains in Chap. 8 how the judiciary in that country, and in particular the Constitutional Court, has established itself as the most important instrument in developing and protecting constitutionalism. In this system, Koopmans' above-mentioned notion of bipolar constitutionalism is plain to see. Venter's analysis also shows the tensions generated by seeking to protect constitutional supremacy through the judicial function in such a fundamental manner.

A reliance on the judicial branch to safeguard the country's Constitution is also apparent in German constitutionalism. In Chap. 3 on Germany, Anja Seibert-Fohr explains that the constitutional role of judges is key in balancing the tension between democracy and the rule of law in a system where the courts have a duty to protect the Constitution. She stresses the 
interplay of democratic legitimation and the qualification of professional judges in making judicial appointments. But there is more: in her view, constitutional jurisprudence itself also plays an important role in striking a balance in the same bipolar zone of conflict. The methodology of interpretation and the judges' practice of restraint concerning political decisions concretise their relationship to democratically legitimated majority decisions.

As Evelyne Maes illustrates in Chap. 2 on the Belgian Constitutional Court, the independence of an institution is determined not only by the constitutional entrenchment of its existence, competences and composition and by its normative, organizational and financial autonomy, but also by the independence and impartiality of each of its members. Although she concludes that the Belgian Constitutional Court is a strong and independent institution, she is critical of cuts in the Court's funding, as well as of the procedure for nominating new judges. This procedure does not always involve a parliamentary hearing, at least not necessarily one of a serious nature, while, in her view, Parliament's involvement in the appointments procedure is crucial if constitutional judges are to have true democratic legitimacy.

The appointment of judges is also a matter of discussion in Norway, as the contribution by Eivind Smith shows. Unlike many other countries, Norway has not assigned the task of judging the constitutionality of formal legislation and other acts of parliament to a constitutional court, but instead to courts of general jurisdiction. In such a system, where judges may be involved in the task of authoritative norm-setting, it could be argued that it is far from obvious that judicial independence requires judges to be selected in complete isolation from the political branches of government. In Chap. 6 Smith contends that elements of open political appointments may even be necessary to ensure a sufficient level of legitimacy, regardless of the high level of social trust present in that country.

Whereas most contributions to this volume focus on the independence of the judiciary in states, Chap. 10 by Marios Costa examines the role played by the Court of Justice of the European Union with regard to accountability in the EU. In analysing the EU access to documents regime from a perspective of accountability, Costa argues that the case law of the Court creates a substantial accountability gap because of restricting the right to access documents.

In addition to the European Union, the Council of Europe offers a constitutional metalevel on a pan-European scale. This applies particularly in the case law of the ECtHR, but also in the Council's efforts as an institution, fuelled by the 'Venice Commission'. With regard to the Council of Europe, Jörg Luther in Chap. 9 examines the general principles of judicial independence and legal accountability as they relate to the ECtHR and calls for the further development of the Court's institutional independence. Meanwhile, in Chap. 12 Eirik Holmøyvik and Anne Sanders outline the elements of a stress test for judicial independence, concluding with the pertinent question of whether it is the constitutional arrangement or rather the constitutional culture that ensures the independence of the judiciary.

\subsection{Deliberative Constitutionalism}

The most important source of legitimacy for judicial decisions is the legality of the law in force, which always needs to be explained when being applied. In the past, the law in force was viewed as a single legal order, but today's reality of a multi-layered order and multi-level governance makes this much more complicated. Judges have to identify the sources of their legitimacy in this complex legal structure. We are no longer talking here of a single legitimating legal source (usually a certain piece of legislation), but rather of a plurality of anchor points in a complex network. Within the confines of a single legal order, it could be assumed that the law is something that can be found 'out there'. In a pluralist, layered legal order, however, judges are 
themselves co-actors in a dynamic process, such as that of European legal development. ${ }^{14}$ The legitimacy of a judicial decision is not implied by the democratic content of the sources of law on which it is based, but instead requires further deliberation and argumentation. This is especially true for international judges, whose constitutional embeddedness is quite rudimentary, ${ }^{15}$ and for constitutional judges, whose work begins where the highest legislative bodies have left ambiguity. ${ }^{16}$

In all these situations - in one more so than the other - judges themselves become actors in the deliberative constitutionalism characterizing a democratic society: 'Judicial decision can trigger dialogue. ${ }^{17}$ It is a role that judges cannot evade in a democratic society, and they have to fulfil it in an acceptable, procedurally legitimating way. Like other actors in this process, judicial institutions have to define their own constitutional position in interaction with the other institutions and the citizens of the state. The more effectively the safeguards that anchor judges in the constitutional system function, the more judges will be able to avoid rigidity in respect of the limits set on their role.

In the meantime, changes in political culture mean these political state institutions are themselves involved in a fundamental transformation of what they understand their function to entail, particularly as a result of the vehement desire for direct control that, through the ballot box, is challenging the moderating effect of guarantees of fundamental rights and the rule of law. The judiciary cannot maintain these guarantees if political support is weakening. Several contributions to this volume provide examples of political criticism and pressure on the judiciary, against which the usual guarantees are unable to provide protection. The pressure on judges in many states shows that the risk of the rule of law being eroded is not limited to the EU Member States Poland and Hungary, which are being criticised in various EU circles, as evidence of the fragility of constitutional arrangements in times when power questions dominate is visible in other countries as well.

When judicial power comes into direct confrontation with political power, the very foundations of a constitutional system are put to the test. The rejection, especially by populist movements, of judicial rulings that protect the weak is a phenomenon perceptible in many Western democracies today. If their rigorous rejection of migrants, for example, is not compatible with judicial review, such movements boast of voicing the 'will of the people'. A constitutionalist-minded response requires careful argumentation and should focus specifically on confirming what all state institutions need: a legitimacy that ultimately lies in the principle of protecting every human being and everyone's life situation, including in a political and economic sense.

Complex systems, to which democratic constitutional orders under the rule of law unquestionably belong, encompass a multitude of stabilizing and destabilizing features. Going back to the idea of merely 'separating' powers is desperately inadequate. This is why a convincing and effective response to threats to the judiciary's independence requires a detailed and precise analysis of the judiciary's constitutional safeguards and limits.

\footnotetext{
${ }^{14}$ Hirsch Ballin 2004.

${ }^{15}$ Von Bogdandy and Venzke 2014, p 215.

${ }^{16}$ Möllers 2011.

17 Young 2018, p 133.
} 


\section{References}

Achterberg N (1969) Antinomien verfassunggestaltender Grundentscheidungen. Der Staat $8: 159-180$

Ackerman B (2017) Good-bye, Montesquieu. In: Ackerman S R et al (eds) Comparative Administrative Law. Edward Elgar, Cheltenham, pp 38-43

Adams L H J et al (eds) (2017) Constitutionalism and the Rule of Law: Bridging Idealism and Realism. Cambridge University Press, Cambridge

AIV (2017) The will of the people? The erosion of democracy under the rule of law in Europe. Adviesraad voor Internationale Vraagstukken, The Hague

Bell J (2006) Judiciaries within Europe: A Comparative Review. Cambridge University Press, Cambridge

Claes M (2006) The National Courts' Mandate in the European Constitution. Hart Publishing, Oxford/Portland

Hirsch Ballin E M H (2004) Reflections on co-actorship. In: Hirsch Ballin E M H, Senden L (eds) Co-actorship in the Development of European Law-Making: The Quality of European Legislation and its Implementation and Application in the National Legal Order. T.M.C. Asser Press, The Hague, pp 3-23

Koopmans T (2003) Courts and Political Institutions: A Comparative View. Cambridge University Press, Cambridge

Möllers Ch (2011) Legalität, Legitimität und Legitimation des Bundesverfassungsgerichts. In: Jestaedt $\mathrm{M}$ et al (eds) Das entgrenzte Gericht: Eine kritische Bilanz nach sechzig Jahren Bundesverfassungsgericht. Suhrkamp, Berlin, pp 281-405

Robertson D (2010) The Judge as Political Theorist: Contemporary Constitutional Review. Princeton University Press, Princeton/Oxford

Rosanvallon P (2008) Counter-Democracy: Politics in an Age of Distrust. Cambridge University Press, Cambridge

Stone Sweet A (2004) The Judicial Construction of Europe. Oxford University Press, Oxford Tushnet M (2018) Advanced Introduction to Comparative Constitutional Law. Edward Elgar, Cheltenham/Northampton MA

Van der Schyff G (2005) Limitation of Rights: A Study of the European Convention and the South African Bill of Rights. Wolf Legal Publishers, Nijmegen

Venter F (2010) Global Features of Constitutional Law. Wolf Legal Publishers, Nijmegen

Von Bogdandy A, Venzke I (2014) In wessen Namen? Internationale Gerichte in Zeiten globalen Regierens. Suhrkamp, Berlin

Young A L (2018) Dialogue, Deliberation and Human Rights. In: Levy R et al (eds) The Cambridge Handbook of Deliberative Constitutionalism. Cambridge University Press, Cambridge, pp 125-138 